\title{
Postharvest practices and farmers' perception of cocoa bean quality in Cameroon
}

\author{
Lewis Dopgima Levai ${ }^{1}{ }^{2 *}$, Henry Dilonga Meriki ${ }^{1}$, Amayana Adiobo ${ }^{2}$, Sama Awa-Mengi ${ }^{3}$, \\ Jane-Francis Tatah Kihla Akoachere ${ }^{1}$ and Vincent P. K. Titanji ${ }^{4}$
}

\begin{abstract}
Background: After the closure of Cameroon's National Produce Marketing Board in 1990, rigorous measures no longer existed to control production of quality cocoa. This study assesses farmers' knowledge of postharvest practices that could influence cocoa bean quality (CBQ), their perception of quality cocoa and the factors that hinder good farming and postharvest practices (GFPHP). We also make suggestions on how quality control can be incorporated in the production chain to improve on CBQ produced.
\end{abstract}

Methods: In a cross-sectional, purposive study in Fako Division, South West Region of Cameroon, 100 farmers were enrolled from 10 villages (10 from each village) which make up the major production area in Agro-ecological Zone IV of Cameroon. Farmers were administered a semi-structured questionnaire in the language they best understood.

Results: Cocoa farming in this area is a tradition and our results show that $97 \%$ of farmers are males and acquired farming practices mainly through their family member (43\%) and/or friends (34\%). Farms are self-owned, 76 and $85 \%$, respectively, are less than $5 \mathrm{Ha}$ and have been cultivated for more than 20 years. Only $10 \%$ of farmers could perceive quality cocoa using physical characterization. Although more than $95 \%$ of farmers knew GFPHP, only $48 \%$ undertake these practices. Farmers' focus was on bean weight and not on CBQ and $64 \%$ of farmers think quality has little impact on the price. Most farmers (71 \%) sell to "buyam-sellams" who care little about quality. The proportion of respondents who acquired knowledge through formal learning was significantly higher than those who did so from informal learning with regards to both good cocoa production practice $(p=0.036)$ and appreciation of quality attributes $(p=0.043)$. Subsidizing inputs, access to credits, creating cooperatives, regulating price of cocoa and training on postharvest management in decreasing order could enhance practices that will ensure quality cocoa production.

Conclusion: GFPHP is important in the production of quality cocoa. Left alone, farmers will not pay attention to these quality attributes especially as premium quality is not rewarded. Organizing farmers into cooperatives will reduce the link between farmers and companies exporting cocoa and alleviate most bottlenecks in the sector.

Keywords: Cocoa bean, Perception, Postharvest, Quality

\section{Background}

Cocoa is one of the main cash crops in Cameroon. Cameroon produced 264,077 million tons of cocoa in 2010 [1]. This production dropped to 209,905 million tons in 2013 and rose a little to 232,530 million tons in 2014. This makes Cameroon the fifth world cocoa producing nation after Ivory Coast, Ghana, Indonesia and Nigeria

\footnotetext{
*Correspondence: doplevai@yahoo.co.uk

2 JP Johnson Biotechnology Laboratory, Institute of Agricultural Research

for Development (IRAD) Ekona, PMB 25, Buea, Cameroon

Full list of author information is available at the end of the article
}

[2]. Presently, the Government of Cameroon projects that with an increase in availability of planting material and the opening of new farms with the help of National Cocoa Development Board that will assist farmers with acquisition of planting materials and accompany them in planting this amount will swell to 600,000 million tons by 2020 . This will increase the overall quantity produced but the amount per hectare still remains low. Despite all these, the cocoa sector in Cameroon is still not fully controlled. In 1990, the National Produce Marketing Board (NPMB) was closed down. This board was a government structure 
that acted in the control of quality and marketing of cocoa beans. After this closure, government involvement was greatly reduced in this sector. Farmers were abandoned to themselves and since they could now sell to anyone ready to buy, stringent measures are no longer taken to guarantee the production of quality cocoa. Licensed Buying Companies (LBC) no longer respected bean quality and buying operations have been left to middlemen ("buyamsellam") who most of the time are not trained and always in a haste to meet their required monthly tonnage. These forces have greatly compromised the quality of cocoa leaving Cameroon for foreign markets.

The cocoa tree is cultivated principally for cocoa beans. These beans are the principal raw material for the manufacturing of chocolate and other cocoa-based beverages. Inside the cocoa pod (the fruit) is a mucilaginous pulp which represents approximately $40 \%$ of the fruit fresh weight [3]. It is composed of a spongy mucilaginous tissue containing cell sap.

The pulp is the substance that is seen immediately after the pod is opened. It is white, juicy and rich in fermentable sugars such as glucose, fructose and sucrose. It also contains salts (8-10\%), pentosans (2-3\% pectin), organic acids (1-2\%) and $0.6 \%$ proteins [3-5]. The pulp has a high concentration of acids, especially citric acid, 2.1-2.4\% (w/w), and also has smaller amounts of other organic acids present such as lactic acid, $0.03 \%(\mathrm{w} / \mathrm{w})$ and acetic acid, $0.04 \%$ (w/w) [6, 7]. During on-farm processing, this mucilaginous pulp is degraded by microbial fermentation, producing a running liquid known in the industry as 'sweating' [5]. Fermentation, was considered as simply an easy way to remove the pulp to facilitate drying, but its importance to cocoa quality has been well established [4].

The ethanol and acetic acid that diffuse through the seed coat, combined with the heat produced by the exothermic bioconversion of ethanol, causes the death of the seed embryo and marks the end of the fermentation [8, 9]. These changes induce an array of biochemical reactions within the beans and generate the chemical precursors of chocolate flavour, aroma and colour [10-13]. Other factors such as agronomic management, soil and weather characteristics, as well as postharvest technology, also contribute to chocolate flavour [14].

Cocoa bean is the seed found within the fruit pod embedded in the mucilaginous pulp. The bean is whitish when young and turns brown as it gets matured. Raw cocoa beans have an astringent, unpleasant taste and flavour. The final chocolate flavour is influenced by the origin and cultivar of the cocoa beans, on-the-farm fermentation, drying, roasting and further processing performed by the cocoa and chocolate manufacturer [10, 15-18].
Seating in its sixteenth meeting in Berlin in 2008, Consultative Board on the World Cocoa Economy agreed that cocoa of merchant quality must be fermented, thoroughly dry, and free from smoky or broken beans, abnormal or foreign odours and any evidence of adulteration, reasonably uniform in size, reasonably free from broken beans, fragments and pieces of shell, and be virtually free from foreign matter. In Cameroon, because of pressure by "buyam-sellams" on the farmers to sell their produce and the fact that quality is not usually considered when buying and selling is done, farmers hardly respect these norms.

According to previous reports [19] market-determined premiums in commodity markets are based among other factors on quality perceptions. Folayan [20] explained that the root cause of quality anomalies in cocoa could be traced to poor farm management, infestation and other diseases, poor handling, bad fermentation, inadequate drying leading to high moisture content which makes the produce vulnerable to mold and bacterial growth. Other causes of low quality cocoa are poor and long storage time which result in fat degradation and pest infestation in the absence of fumigation and other forms of quality maintaining measures.

In this study, we assess farmers' knowledge of postharvest practices that contribute to quality cocoa bean. Their perception of good quality cocoa and the factors that make it difficult for them to practice these technologies have also been examined. Suggestions have also been made on how quality control can be included in the production chain to improve on the quality of cocoa bean produced in the South West Region of Cameroon.

\section{Methods}

This study was conducted in Fako Division of the South West Region, Cameroon. The South West Region is the major production area in Agro-ecological Zone IV characterized by a forest and a mono-modal rainfall pattern. Ten villages (Bafia, Ikata, Likoko Mile 15, Lilale, Malende, Maumu, Muea, Munyenge, Owe and Yoke) were purposively selected for this study. These villages are amongst those with high cocoa production in this production basin and are closer to the Institute of Agricultural Research for Development (IRAD). It is believed that farmers would be more accessible to research and other technologies that have been developed by IRAD.

The questionnaire was designed to collect information on demography, experience and how knowledge of the cocoa production process was acquired, what kind of postharvest practice they carry out, what limitations they have and suggestions to overcome these limitations. One hundred farmers (10 per village) were 
randomly enrolled and each of them was administered a semi-structured questionnaire in the language they best understood after an informed consent. Each participant signed a consent form. Authorisation (Ref: 0012/MINRESI/RCSR/01/2014) for this study was obtained from Southwest Regional Centre of the Ministry of Scientific Research and Innovation.

The responses were keyed in an MS excel spread sheet and analysed using the Statistical Package for Social Sciences, SPSS software. Results have been presented as frequency and percentages in tables and figures. Categorical comparisons were performed with Chi-square test. Odds ratios (ORs) and nominal $95 \%$ confidence intervals (CIs) were presented. A two-sided $p$ value $<0.05$ was considered significant for all analyses.

\section{Results}

\section{Demographic and socioeconomic characteristics of respondents}

Cocoa farming in this area is an activity of the middle aged with $70 \%$ of farmers in the age group 31-50. More than $80 \%$ of the farmers are married and have attended school to at least junior secondary (Table 1). The farms are mostly self-owned with, $85 \%$ less than $5 \mathrm{Ha}$. The majority (62 \%) have been under cultivation for more than 10 years. Cocoa farming in study area is a tradition and results show that they learned farming practices mainly from their family (43\%) or friends (34\%).

\section{Perception of quality cocoa based on physical characteristics}

Farmers were asked to describe the characteristics based on what they know to be quality cocoa. For each quality attribute (Colour, shell, bean and odour) a table with correct and incorrect responses was provided for them to choose. Based on the present understanding of what is required for the physical characterization of $\mathrm{CBQ}$, most farmers concentrate on the colour, the bean and odour (whether it is smoky). Farmers easily could tell the odour (94\%), external colour (70 \%) and internal colour (64\%) of good quality bean but only $20 \%$ could appreciate the quality of the shell as shown in Fig. 1.

To perceive quality cocoa bean, all these attributes are supposed to be correct. When they were put together, only $10 \%$ (Fig. 2) would come out with premium quality beans. Fifty-seven (57) percent had less than three attributes correct (poor bean).

\section{Good farming practices to ensure quality cocoa}

Some of the cultural practices were listed and farmers asked to comment on their level of importance to obtaining quality cocoa. Based on their responses as shown in Table 2, apart from use of fertilizer, all of the practices
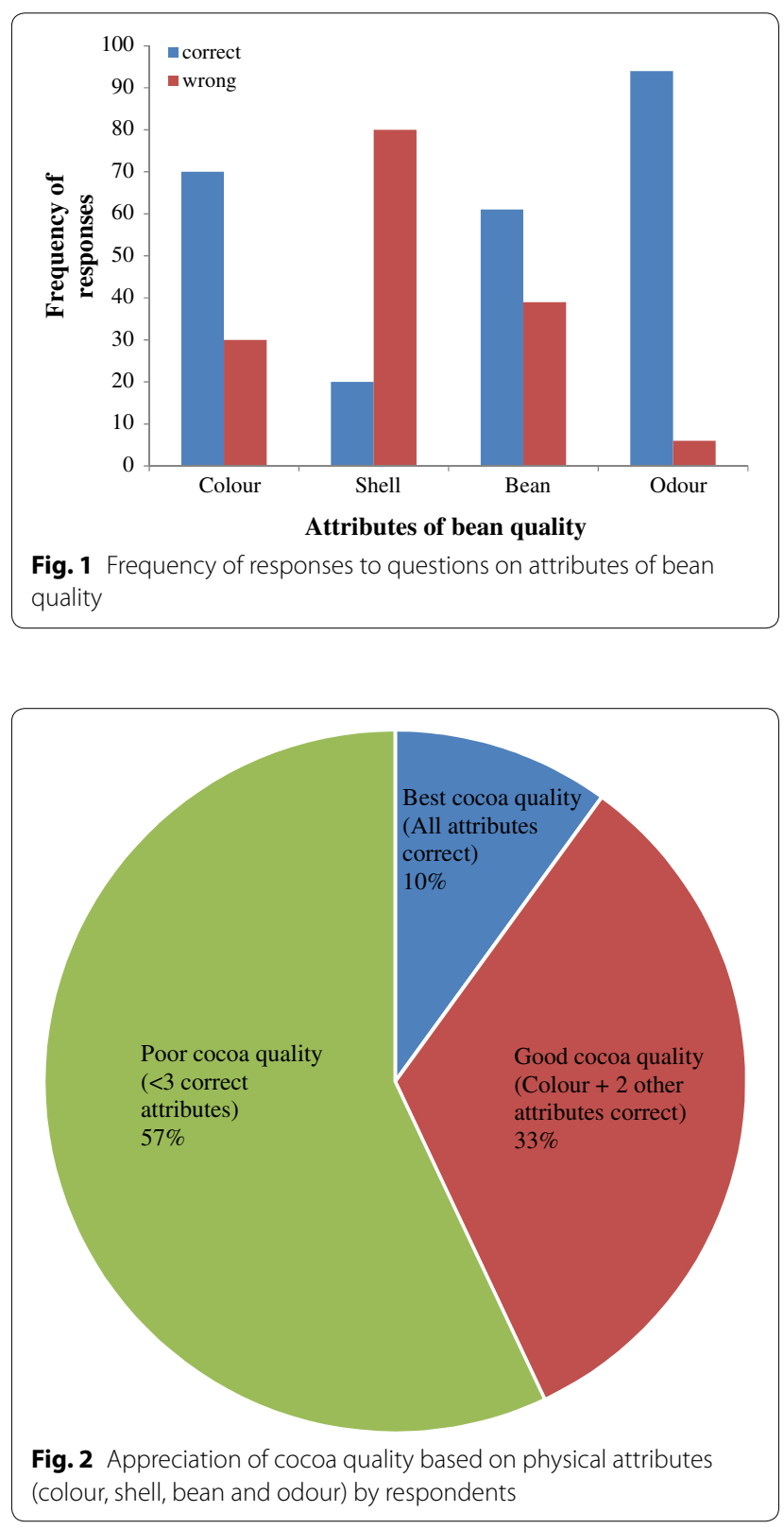

were very important to ensure the production of quality cocoa bean.

We went ahead and asked farmers whether they carry out these practices in their farms to ensure that they always have quality cocoa at the end of each cycle. From the responses we realized that more than $95 \%$ of farmers always spray the pods, prune the branches, ferment and dry their beans. However, $31 \%$ of farmers will not plant improved varieties either because they do not yet have access to these varieties, do not have new land, no knowledge, or the fact that these improved varieties fall after 3 years due to a production that cannot be supported by 
Table 1 Demographic and socioeconomic characteristic of respondents

\begin{tabular}{|c|c|c|c|}
\hline Characteristics & Category & Frequency & Valid percent \\
\hline \multirow[t]{2}{*}{ Marital status } & Married & 84 & 86.6 \\
\hline & Single & 13 & 13.4 \\
\hline \multirow[t]{5}{*}{ Age group (years) } & $21-30$ & 7 & 7.1 \\
\hline & $31-40$ & 35 & 35.7 \\
\hline & $41-50$ & 35 & 35.7 \\
\hline & $50-60$ & 12 & 12.2 \\
\hline & $>60$ & 9 & 9.2 \\
\hline \multirow{4}{*}{$\begin{array}{l}\text { Level of education (years of } \\
\text { school) }\end{array}$} & $<7$ & 6 & 6.0 \\
\hline & $7-11$ & 64 & 64.0 \\
\hline & $12-16$ & 24 & 24.0 \\
\hline & $>16$ & 6 & 6.0 \\
\hline \multirow[t]{2}{*}{ Size of farm (hectares, $\mathrm{Ha}$ ) } & $<5 \mathrm{Ha}$ & 85 & 85.0 \\
\hline & $>5 \mathrm{Ha}$ & 15 & 15.0 \\
\hline \multirow[t]{3}{*}{ Farm owner } & Family & 14 & 14.0 \\
\hline & Landlord & 10 & 10.0 \\
\hline & Self & 76 & 76.0 \\
\hline \multirow[t]{4}{*}{ Occupation } & Applicant & 1 & 1.0 \\
\hline & Business & 8 & 8.0 \\
\hline & Civil servant & 2 & 2.0 \\
\hline & Farming & 89 & 89.0 \\
\hline \multirow[t]{4}{*}{ Age of farm (years) } & $\leq 10$ & 22 & 22.4 \\
\hline & $11-20$ & 39 & 39.8 \\
\hline & $21-30$ & 28 & 28.6 \\
\hline & $>30$ & 9 & 9.2 \\
\hline \multirow[t]{3}{*}{ Duration in farming (years) } & $<5$ & 8 & 8.0 \\
\hline & $5-10$ & 30 & 30.0 \\
\hline & $>10$ & 62 & 62.0 \\
\hline \multirow{5}{*}{$\begin{array}{l}\text { Acquisition of farming kno- } \\
\text { whow }\end{array}$} & Cooperative & 17 & 17.0 \\
\hline & Family & 43 & 43.0 \\
\hline & Farmers field & 5 & 5.0 \\
\hline & School & 34 & 34.0 \\
\hline & Friend & 1 & 1.0 \\
\hline \multirow{2}{*}{$\begin{array}{l}\text { Formal training on posthar- } \\
\text { vest technology }\end{array}$} & No & 49 & 49.0 \\
\hline & Yes & 51 & 51.0 \\
\hline
\end{tabular}

the root system. Of the $74 \%$ of farmers who do not use fertilizers in their farms more than half (62\%) attribute it to the high cost and $18 \%$ think that it is of no use since their soil is fertile.

Due to the fact that quality is not checked, some farmers (10\%) will not remove diseased pods from the pile. They explained that diseased beans contribute to weight during sales and they do not sort them out as this process is laborious. Whether sorting is done or not does not affect the price, they explained.

Survey data indicate that more than half (52\%) of farmers do not ferment their bean. Fermentation, when done, is mostly carried out for 4-6 days in bags. To achieve this, the pods are opened and pod content filled in $50 \mathrm{~kg}$ bags. This permits farmers to easily transfer them from the field on motorbikes to either their homes or to ovens for drying. Some farmers $(7 \%)$ carry out fermentation for less than 4 days either because of their turn to use the oven or to get the beans out quickly to a waiting buyer.

Farmers were further asked to list in order of importance three things that would allow them obtain good quality cocoa. According to the results (Fig. 3), farmers would prefer to spray, prune trees and clear their farms in that order. Fermentation and drying only comes afterwards. Upon further questioning (not included in the questionnaire), they indicated that their intention is to have a good harvest and high weighted beans and not how good looking these beans are. Of all the respondents, $64 \%$ said quality will not affect price while only $11 \%$ considered quality cocoa to attract a higher price.

Most farmers $(71 \%)$ market their beans to middlemen while very few (5\%) sell directly to exporters. In some of the areas, cooperatives have been developed and $24 \%$ of the respondents now sell directly to their cooperatives. This contributed to the fact that $52 \%$ of farmers would not grade their cocoa due to the fact that buyam-sellams do not have a grading scheme and they propose the same price irrespective of. However, $35 \%$ would always grade to check humidity and $13 \%$ will do so only sometimes.

Based on farmers' responses, we could observe that only $48 \%$ undertake practices that could ensure quality cocoa bean as shown in Fig. 4.

\section{Factors that influence good cocoa practices and appreciation of quality attributes}

The proportion of respondents who acquired knowledge through formal [cooperatives and Farmer Field School (FFS)] learning was significantly higher than those who did so from informal (family, friends and self) learning with regards to both good cocoa practice (OR 2.86, $95 \%$

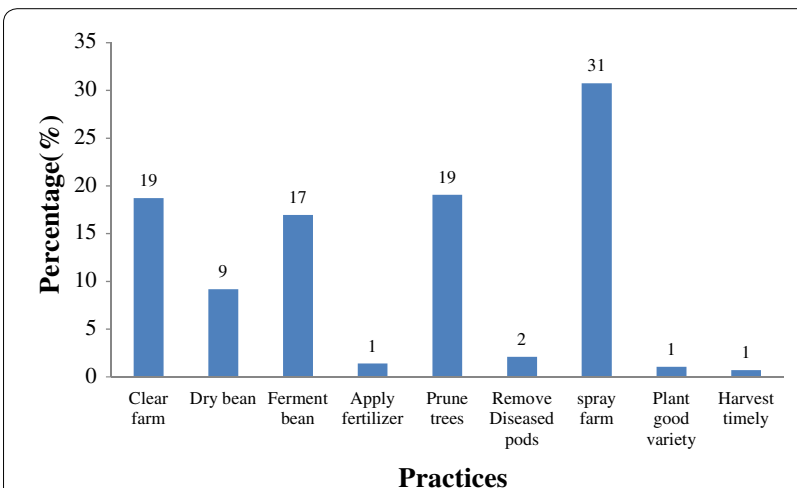

Fig. 3 Frequency of responses on agricultural practices carried out by farmers to ensure production of quality cocoa 


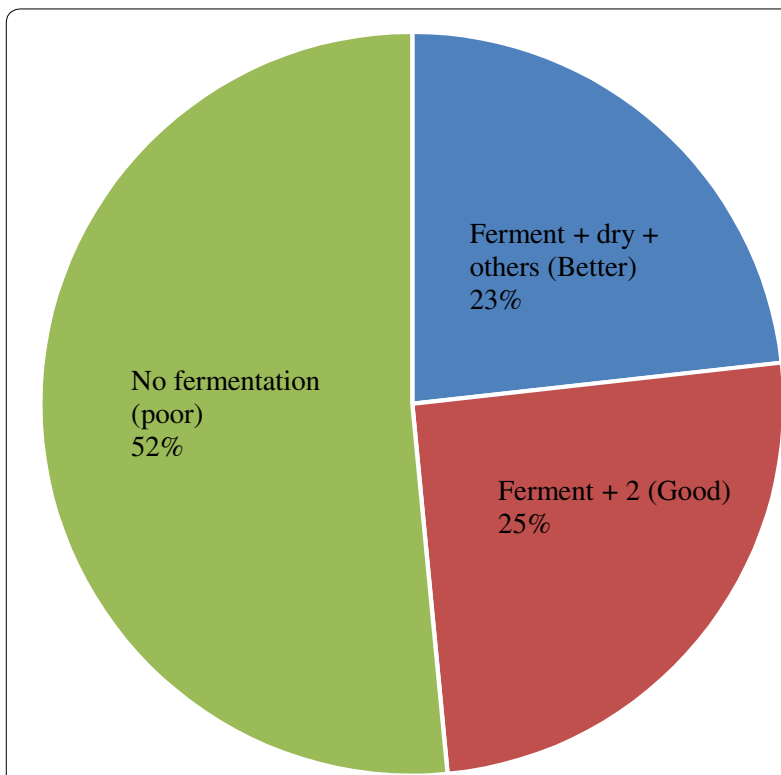

Fig. 4 Use of fermentation and other postharvest practices by farmers to ensure production of quality cocoa

Table 2 Appreciation of agricultural practice to ensure production of quality cocoa

\begin{tabular}{llll}
\hline Practice & \multicolumn{2}{l}{ Frequency of category } \\
\cline { 2 - 4 } & $\begin{array}{l}\text { Not } \\
\text { important }\end{array}$ & $\begin{array}{l}\text { Not so } \\
\text { important }\end{array}$ & $\begin{array}{l}\text { Very } \\
\text { important }\end{array}$ \\
\hline Plant good variety & 2 & 8 & 90 \\
Use of fertilizer & 9 & 20 & 71 \\
Spray farm & 0 & 1 & 99 \\
Prune farm & 0 & 0 & 100 \\
Remove diseased pods & 1 & 4 & 95 \\
Ferment bean & 0 & 0 & 100 \\
Dry bean & 0 & 0 & 100 \\
\hline
\end{tabular}

CI 1.05-7.80, $p=0.036$ ) and quality attributes (OR 2.68, $95 \%$ CI 1.10-7.06, $p=0.043$ ) as shown in Table 3. This was observed when a farmer is under a landlord/family land as opposed to when farm was self-owned (OR 2.70, $95 \%$ CI 1.02-7.14, $p=0.041$ ) and when training on postharvest techniques was formal as to informal (OR 2.86, $95 \%$ CI 1.05-7.80, $p=0.036$ ). While the other factors did not show a significant difference, only farm ownership significantly influenced good cocoa practice.

\section{Farmers' recommendations to ameliorate cocoa production}

Farmers were finally asked to make recommendations as to what they think could be done to permit them produce quality cocoa all the time. The most prominent suggestions were that there be subsidies for inputs $(33.85 \%)$, access to credit (18.08\%) and the formation of cooperatives (10.77 \%) (Fig. 5).

\section{Discussion}

The dream of every cocoa farmer is to sell their bean at a price that enables them to make maximum gain. This is only possible in a system that is well organized and where premium quality is rewarded. This is presently not the situation that prevails in the cocoa sector in Cameroon. There is available information at the level of IRAD that permits farmers to produce quality cocoa. The process continues to be conducted in a traditional manner as has been noticed in earlier studies [7]. Some of the reasons that hinder them to exploit these technologies have been highlighted in this study.

Fermentation is best conducted in trays, cages or on leaves for 6-7 days [15]. This allows for a single turning of the beans during the second or third day to allow for a proper diffusion of heat and acids. This guarantees a more uniform fermentation and quality bean. In study area, fermentation is carried out in bags and the beans are not turned. Beans from such fermentations are usually not homogenous. Those from the middle of the bag are usually over-fermented while those at the surface are less fermented. This is attributed to the fact that the heat generated during fermentation is less at the surface of the bag and the beans at that location are exposed to acids produced during fermentation only for a short while.

From the responses, we observed that most of the farmers lacked a financial base because production demands a lot in terms of availability and timely application of inputs. With the increase in subsidies and/or availability of credit facilities, more than $50 \%$ of the bottlenecks involved in production can be overcome. These subsidies can be provided to farmers as either production inputs that ranked first $(33.85 \%)$ and/or access to credits that ranked second (18.08\%).

To achieve this, farmers themselves have realized that they need to create cooperatives. Cooperatives on the one hand will reduce the long chain that exist between producers and exporters and on the other hand put in place a valid control system for monitoring production of cocoa bean. If this is done, grading of bean can be instituted such that premium quality bean can thus fetch higher prices.

In the days of the NPMB, production capacity of farms of affiliated members could be evaluated and farmers given loans in terms of inputs and/or credit (mostly as inputs) and this amount deducted from their sales. The board could equally assist the farmers when they needed money at very low or no interest and keep their produce to sell when market prices are good because they had good storage facilities. When the NPMB closed down, most farmers fell their trees as it was no longer profitable to farm cocoa. 


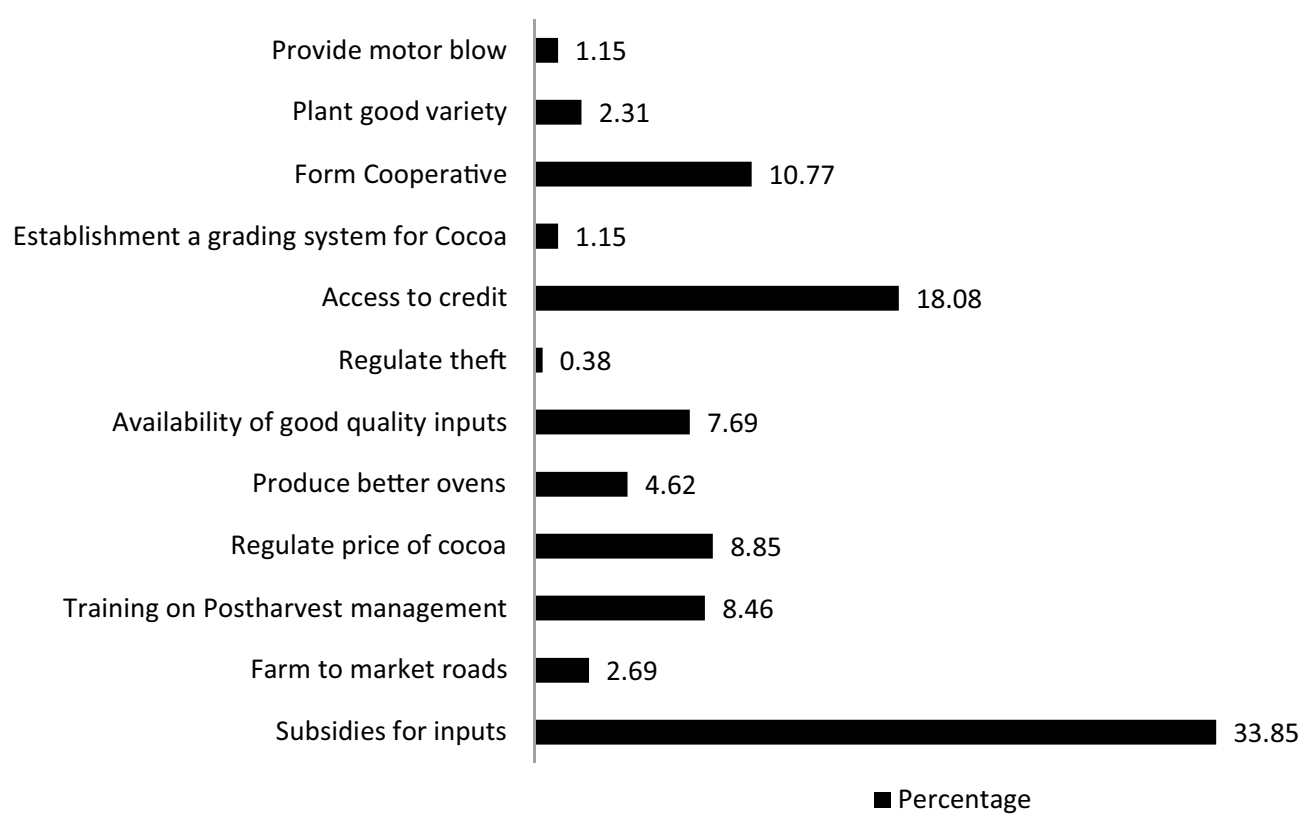

Fig. 5 Recommended factors that could ameliorate cocoa production

When middlemen are involved, the marketing chain is long. This places the farmer far from the LBCs and reduces their bargaining power. These middlemen are interested in getting their tonnage for the required LBC as fast as possible and they would hurry the farmers not to even ferment or properly dry beans. Poor resource farmers equally want to make fast money and solve problems or repay an outstanding loan. Faced with this pressure from the middlemen, they heed and this affects the quality that gets to the market.

Lack of training on postharvest technologies was equally raised as a factor that affects the quality of cocoa produced. We noticed that $52 \%$ (Fig. 4) of the farmers we interviewed do not ferment their beans. When fermentation is carried out, it is done in bags and this does not allow for turning of the beans thus some end up overfermented (in the middle of the bag) and some poorly fermented (close to the surface of the bag). The recommended process is to carry out the fermentation either on the ground or in cages or trays covered with banana leaves for 6-7 days. Farmers use 3-5 days when they ferment as equally noticed by Takrama [21] and Bariah [22]. Duration of fermentation is also influenced by the turn of the farmer to use the oven for drying or the pressure to sell to a waiting buyam-sellam.

Farmers have learned over the past few years to carry out fermentation in bags from their families (43\%) and friends (34\%) Table 3. Most of those who are close to cooperatives and FFS of the Ministry of Agriculture and Rural
Development (MINADER) have started using these structures. There was a significant difference in the way the farmers who used the service of formal structures would appreciate and undertake GFPHP when compared to others. It is therefore important that the government through MINADER multiplies these FFS to be close to or present in production basins. Most of the farmers have farming as their principal activity (89\%) and with more than $90 \%$ being able to read and write, the transfer of technologies becomes easier with the use of technical bulletins and practical knowledge in FFS. When farmers were recruited in the Cocoa High Technology Programme in Ghana, 88 \% applied the good cocoa practice in their farms to produce quality beans [23].

The fact that farmers always need some form of control was confirmed by the fact that those who worked in farms that they did not own, significantly $(p=0.041)$ undertake good production practices as opposed to those working on their farms (Table 3). This can be explained by the fact that farm owners controlled the way the cocoa production was carried out.

\section{Conclusion}

Good farming and postharvest practice is important in the production of quality cocoa. Left on their own, farmers will not pay attention to these quality attributes especially as premium quality is not rewarded. Organizing farmers into cooperatives is important in reducing the chain that exists between farmers and LBCs that export cocoa. 
Table 3 Factors that influence good cocoa practices and appreciation of quality attributes among farmers

\begin{tabular}{|c|c|c|c|c|c|c|c|}
\hline \multirow[t]{2}{*}{ Characteristics } & \multirow[t]{2}{*}{ Categories } & \multicolumn{2}{|c|}{$\begin{array}{l}\text { Good cocoa practice } \\
(\%)\end{array}$} & \multirow{2}{*}{$\begin{array}{l}\text { Odds ratios } \\
(\mathrm{Cl}, \mathrm{p} \text { value })\end{array}$} & \multicolumn{2}{|c|}{ Quality attributes (\%) } & \multirow{2}{*}{$\begin{array}{l}\text { Odds ratios } \\
(\mathrm{Cl}, \mathrm{p} \text { value })\end{array}$} \\
\hline & & Good & Poor & & $\begin{array}{l}\text { All } 4 \\
\text { correct }\end{array}$ & $\begin{array}{l}\text { Less than } \\
4 \text { correct }\end{array}$ & \\
\hline \multirow[t]{2}{*}{ Age group (years) } & $<40$ & $16(39.0)$ & $25(61.0)$ & $0.56(0.25-1.26,0.156)$ & $18(45.0)$ & $22(55.0)$ & $1.30(0.57-2.96,0.528)$ \\
\hline & $\geq 40$ & $30(53.6)$ & $26(46.4)$ & 1 & $22(38.6)$ & $35(61.4)$ & 1 \\
\hline \multirow{2}{*}{$\begin{array}{l}\text { Level of education (years of formal } \\
\text { education) }\end{array}$} & $\leq 12$ & $31(44.9)$ & $38(55.1)$ & $0.62(0.263-1.48,0.283$ & $31(44.9)$ & $38(55.1)$ & $1.90(0.76-4,75,0.164)$ \\
\hline & $>12$ & $17(56.7)$ & $13(43.3)$ & 1 & $9(30.0)$ & $21(70.0)$ & 1 \\
\hline \multirow[t]{2}{*}{ Farm ownership } & $\begin{array}{l}\text { Others } \\
\text { (Landlord } \\
\text { and family) }\end{array}$ & $16(66.7)$ & $8(33.3)$ & $2.70(1.02-7.14,0.041)$ & $12(52.2)$ & $11(47.8)$ & $0.54(0.21-1.37,0.189)$ \\
\hline & Self & $32(42.7)$ & $43(57.3)$ & 1 & $28(36.8)$ & $48(63.2)$ & 1 \\
\hline \multirow[t]{2}{*}{ Duration in farming (years) } & $\leq 10$ & $17(44.7)$ & $21(55.3)$ & $0.78(0.35-1.77,0.556)$ & $16(43.2)$ & $21(56.8)$ & $1.21(0.53-2.76,0.657)$ \\
\hline & $>10$ & $31(50.8)$ & $30(49.2)$ & 1 & $24(38.7)$ & $38(61.3)$ & 1 \\
\hline \multirow[t]{2}{*}{ Acquisition of farming knowledge } & Formal & $15(68.2)$ & $7(31.8)$ & $2.86(1.05-7.80,0.036)$ & $13(59.1)$ & $9(40.9)$ & $2.68(1.01-7.06,0.043)$ \\
\hline & Informal & $33(42.9)$ & $44(57.1)$ & 1 & $27(35.1)$ & $50(64.9)$ & 1 \\
\hline \multirow[t]{2}{*}{ Formal training on postharvest } & Yes & $25(48.1)$ & $27(51.9)$ & $1.04(0.47-2.28,0.932)$ & $19(36.5)$ & $33(63.5)$ & $1.40(0.63-3.14,0.410)$ \\
\hline & No & $23(48.9)$ & $24(51.1)$ & 1 & $21(44.7)$ & $26(55.3)$ & 1 \\
\hline
\end{tabular}

These cooperatives when established will help alleviate the majority of bottlenecks that exist in the sector and restore quality cocoa production in the cocoa farming sector.

\section{Abbreviations}

CBQ: cocoa bean quality; FFS: farmer field school; GFPHP: good farming and postharvest practices; IRAD: Institute of Agricultural Research for Development; LBC: Licensed Buying Companies; MINADER: Ministry of Agriculture and Rural Development; NPMB: National Produce Marketing Board.

\section{Authors' contributions}

LDL, HDM, AA and SAM did the conception and design, data collection and analysis and manuscript writing. JFK and VKPT participated in the critical revision of the manuscript. All authors read and approved the final manuscript.

\section{Author details}

${ }^{1}$ Department of Microbiology and Parasitology, Faculty of Science, University of Buea, PO Box 63, Buea, Cameroon. ${ }^{2}$ JP Johnson Biotechnology Laboratory, Institute of Agricultural Research for Development (IRAD) Ekona, PMB 25, Buea Cameroon. ${ }^{3}$ Department of Sociology and Anthropology, Faculty of Social and Management Sciences, University of Buea, PO Box 63, Buea, Cameroon. ${ }^{4}$ Cameroon Christian University Bali, PO Box 05, Bali, Cameroon.

\section{Acknowledgements}

We wish to thank the farmers immensely for their participation and Marcus AJECHA and Rauwitta OMABIT who helped in the survey. There was no funding for this study.

\section{Competing interests}

The authors declare that they have no competing interests.

Received: 9 September 2015 Accepted: 30 November 2015

Published online: 24 December 2015

\section{References}

1. Food and Agriculture Organization of the United Nations. http://faostat3. fao.org/download/Q/QC/E. Accessed 18 July 2015.
2. Top 10 Cocoa Producing Countries-WorldAtlas.com. http://www.worldatlas.com/articles/top-10-cocoa-producing-countries.html.

3. Schwan RF, Wheals AE. The microbiology of cocoa fermentation and its role in chocolate quality. Crit Rev Food Sci Nutr. 2004;44:205-21.

4. Lopez AS, Dimick PS. Biotechnology. In: Reed G, Nagodawithana TW, Weinheim E editors. Biotechnology. 2nd ed. 1995. p. 561-77.

5. Leal GA, Gomes LH, Efraim P, De Almeida Tavares FC, Figueira A. Fermentation of cacao (Theobroma cacao L.) seeds with a hybrid Kluyveromyces marxianus strain improved product quality attributes. FEMS Yeast Res. 2008;8:788-98.

6. Schwan RF. Cocoa fermentations conducted with a defined microbial cocktail inoculum. Appl Environ Microbiol. 1998;64:1477-83.

7. Ardhana MM, Fleet GH. The microbial ecology of cocoa bean fermentations in Indonesia. Int J Food Microbiol. 2003;86:87-99.

8. Camu N, De Winter T, Verbrugghe K, Cleenwerck I, Vandamme P, Takrama JS, Vancanneyt M, De Vuyst L. Dynamics and biodiversity of populations of lactic acid bacteria and acetic acid bacteria involved in spontaneous heap fermentation of cocoa beans in Ghana. Appl Environ Microbiol. 2007;73:1809-24.

9. Nielsen DS, Teniola OD, Ban-Koffi L, Owusu M, Andersson TS, Holzapfel WH. The microbiology of Ghanaian cocoa fermentations analysed using culture-dependent and culture-independent methods. Int J Food Microbiol. 2007;114:168-86.

10. Hansen CE, Del Olmo M, Burri C. Enzyme activities in cocoa beans during fermentation. J Sci Food Agric. 1998;77:273-81.

11. Hashim P, Selamat J, Muhammad SKS, Ali A. Changes in free amino acid, peptide-N, sugar and pyrazine concentration during cocoa fermentation. J Sci Food Agric. 1998;78:535-42.

12. Cleenwerck I, Gonzalez Á, Camu N, Engelbeen K, De Vos P, De Vuyst L. Acetobacter fabarum sp. nov., an acetic acid bacterium from a Ghanaian cocoa bean heap fermentation. Int J Syst Evol Microbiol. 2008;58:2180-5.

13. Thompson SS, Miller KB, Lopez AS. Cocoa and coffee. In: Doyle MP, Beuchat LR, Montville TJ, editors. Food microbiology: fundamentals and frontiers. 2nd ed. Washington: ASM Press; 2013. p. 881-99.

14. Moreau Cruz JF, Bacelar Leite P, Eduardo Soares S, da Silva Bispo E. Assessment of the fermentative process from different cocoa cultivars produced in Southern Bahia, Brazil. African J Biotechnol. 2013:12:5218-25.

15. Baker DM, Tomlins Kl, Gay C. Survey of Ghanaian cocoa farmer fermentation practices and their influence on cocoa flavour. Food Chem. 1994;51:425-31.

16. De Brito ES, García NHP, Gallão MI, Cortelazzo AL, Fevereiro PS, Braga MR. Structural and chemical changes in cocoa (Theobroma cacao L) during fermentation, drying and roasting. J Sci Food Agric. 2001;81:281-8. 
17. Jinap S, Wan Rosli WI, Russly AR, Nordin LM. Effect of roasting time and temperature on volatile component profiles during nib roasting of cocoa beans (Theobroma cacao). J Sci Food Agric. 1998;77:441-8.

18. Kresnowati MTAP, Suryani L, Affifah M. Improvement of cocoa beans fermentation by LAB starter addition. J Med Bioeng. 2013;2:274-8.

19. Anang BT, Fordjour E, Boateng VF. Farmers' management practices and the quality of cocoa beans in upper Denkyira district of Ghana. Asian J Agric Sci. 2011;3:487-91.

20. Folayan JA. Nigerian cocoa and cocoa by-products: quality parameters, specification and the roles of stakeholders in quality maintenance. Pakistan J Nutr. 2010;9:915-9.
21. Takrama JF. Production of Ghana premium cocoa: primary processing operations. Cocoa Res Inst Ghana. 2006;2:1-6.

22. Bariah K. Impact of fermentation duration on the quality of Malaysian cocoa beans using shallow box. KKU Res J. 2014;19(supplement):74-80.

23. Bosompem Martin, Kwarteng JA, Ntifo-Siaw Edward. Perceived impact of cocoa innovations on the livelihoods of cocoa farmers in Ghana: the sustainable livelihood framework (SI) approach. J Sustain Dev Africa. 2011;13:225-33

\section{Submit your next manuscript to BioMed Central} and we will help you at every step:

- We accept pre-submission inquiries

- Our selector tool helps you to find the most relevant journal

- We provide round the clock customer support

- Convenient online submission

- Thorough peer review

- Inclusion in PubMed and all major indexing services

- Maximum visibility for your research

Submit your manuscript at www.biomedcentral.com/submit

() Biomed Central 